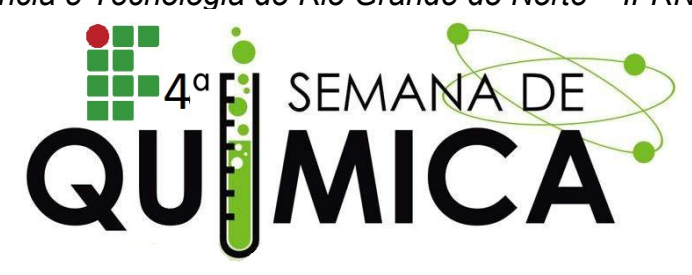

\title{
AVALIAÇÃO DA DETERIORAÇÃO DO AÇO EM DIFERENTES MEIOS CORROSIVOS REVESTIDOS COM ZINCO.
}

\author{
Araújo, E. (IFRN), Varela, J. L. (IFRN), Moreira, T. V. (IFRN), Gonçalves, J. M. (IFRN), \\ Melo, A. M. (IFRN), Penha, F. G. (IFRN)
}

Palavras Chave: corrosão, aço, deposição.

\section{INTRODUÇÃO}

A corrosão é um fenômeno eletroquímico ou químico sobre um determinado material, geralmente metálico. Os problemas de corrosão são frequentes e ocorrem em muitas indústrias química. Os meios corrosivos e métodos de combate a corrosão são aspectos importantes estudados ${ }^{1,2}$. 0 trabalho tem por objetivo avaliar a corrosão de arruelas de aço revestidas ou não com zinco em diferentes meios corrosivos.

\section{METODOLOGIA}

A corrosão de arruelas de aço foram avaliadas em diferentes condições. A superfície do metal foi modificada pela deposição de zinco por eletrólise usando uma bateria de $9 \mathrm{~V}$ e uma solução de $\mathrm{ZnSO}_{4} 1 \mathrm{~mol} / \mathrm{L}$ utilizando um prego como ânodo, como mostrado na Figura 1.

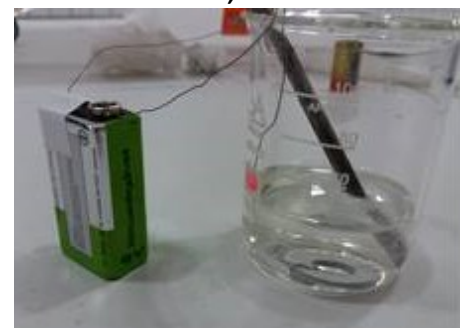

Figura 1 - eletrólise para deposição de zinco sobre o aço.

As peças foram colocadas em contato com água, solução de $\mathrm{NaCl}$, de $\mathrm{HCl}$ e de $\mathrm{NaOH} \mathrm{0,1}$ $\mathrm{mol} / \mathrm{L}$ e a corossão foi acompanhada pela variação de massa em função do tempo (dias).

\section{RESULTADOS E DISCUSSÕES}

Alguns resultados podem ser apresentados pela Figura 2, que mostra a variação de massa num período de 14 dias para o aço com zinco nos diferentes meios corrosivos. Neste período de tempo resultados semelhantes foram obtidos para o aço sem zinco.

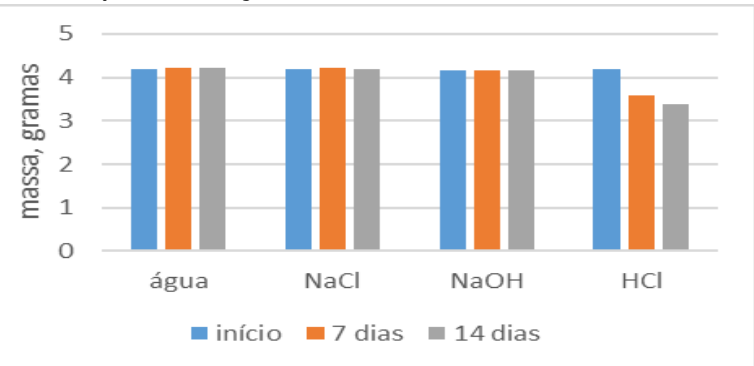

Figura 2 - variação de massa com o tempo durante a corrosão do aço depositado com zinco em diferentes meios.

Observa-se uma variação de massa significativa apenas em meio ácido. Porém, pela Figura 3 tem-se corrosão significativa do aço sem zinco quando comparado com aço com deposição em água.

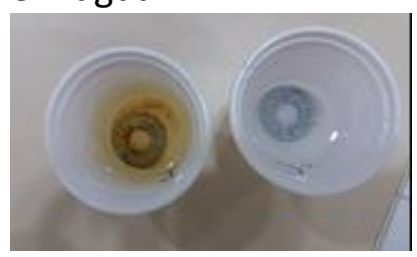

Figura 3 - arruela em contato com água sem deposição de zinco (á esquerda); e com deposição de zinco (á direita).

\section{CONCLUSÃO}

Estudos iniciais indicam forte corrosão do aço em meio ácido e sua proteção em meio aquoso salino e básico através da deposição de zinco.

\section{REFERÊNCIAS}

${ }^{1}$ Gentil, Vicente Corrosão, LTC, 6ạ edição, Rio de Janeiro, 2011.

${ }^{2}$ Merçon, F., et al, Sistema experimentais para o estudo da corrosão em metais, Quimica Nova na Escola, 33 (1), 2011. 